\title{
Evaluation of different solvents for extraction of phytochemical constituents and antioxidant activities of the leaves of Acanthus montanus (Nees) T. Anderson
}

\author{
Ale Joy Enitan ${ }^{1}$, Lawal Ibraheem Oduola ${ }^{1, *}$, and Omogbene Temitope Olorunyomi ${ }^{1}$ \\ ${ }^{1}$ Biomedicinal Research Centre, Forestry Research Institute of Nigeria (FRIN), P.M.B 5054, Jericho Hills Ibadan, Nigeria \\ *Corresponding author: ibroodula@gmail.com
}

Published: December 25, 2021

Received: February 14, 2021

Accepted: April 12, 2021

Published on-line: October 15, 2021

\begin{abstract}
Bear's breech or mountain thistle (Acanthus montanus (Nees) T. Anderson) is a shrub belonging to Acanthaceae family. It is widespread in Africa, Romania, Greece, and Eastern Mediterranean. African people engage its medicinal use for the management of urethral pain, endometritis, urogenital infections, urinary disease, aches and pains. Fresh leaves of $A$. montanus were collected from Forestry Research Institute of Nigeria (FRIN) herbal garden and identified at the Forestry Herbarium, Ibadan. About $200 \mathrm{~g}$ of the powered sample was macerated in $400 \mathrm{~mL}$ each of three organic solvents such as ethyl acetate, acetone and methanol respectively, for $24 \mathrm{~h}$. Each extracts were screened for phytochemicals such as flavonoids, saponins, phenols, terpenoids, phlobotannins, alkaloids, tannins, and cardiac glycosides. Estimation of total flavonol content, and antioxidant assays such as 2,2-diphenyl-1-picrylhydrazyl (DPPH) and nitric oxide radical scavenging activity were also carried out. The quantitative phytochemical test (flavonol content) revealed that Acanthus montanus methanol extract was the richest one among the solvent systems while acetone extract gave the best antioxidant activity. It was observed that the antioxidant activity could be attributed to moderately polar extracts. The study, therefore, provides evidence that various solvents used in extraction can result in differences in quantitative phytochemicals and antioxidant activity.
\end{abstract}

Key words: phytochemical estimation; phytomedicine; free radical; total flavonol; medicinal plant; extraction solvent

http://dx.doi.org/10.5937/leksir2141017A

\section{INTRODUCTION}

Plants are valuable sources of food and medicine for the preservation of human health and management of nutrition-related syndrome (Aliyu et al., 2008; Lawal et al., 2020a). Herbal remedies have been a reliable source that salvaged man's health from various diseases, both mild and life-threatening, before the advent of allopathic drugs (Adam and Omogbene, 2020). In the same vein, plant extracts as well as other alternative forms of medical treatment have made large contributions to human health and well-being (Chukwujekwu et al., 2005). Folk medicine is gaining more attention from researchers which are looking for better drugs against microbial infections (Benkeblia, 2004; Pieme et al., 2008). Moreover, plants use for the management of common and diverse ailments is popular and still sustained among African people (Lawal et al., 2020b; Moyo et al., 2015; Sofowora, 1996).

Over the years, secondary plant metabolites, previously with unknown pharmacological activities, have been thoroughly investigated as a source of medicinal agents (Krishnaraju et al., 2006). Hence, it has been proven that medicinal plants components characterize certain disease prevention capacity, and also proved effective in the treatment of complex cases like cancer as ingredients of medicinal plants all interact synchronously, such that their uses supplement or destroy one another even as they counteract their possible side effects (Hassan, 2012).

Although the study of phytomedicines has drawn the attention of researchers worldwide and alternative medicine has been found to be free from any effect associated with conventional orthodox medicine. However, it is essential to determine the composition of the secondary metabolites and the antioxidants effects to be sure of the level of toxicants and hypothesize the real actions of the bioactive principles resident in plants parts (Bandaranayake, 2006; Hussein and El-Anssar, 2018; WHO, 2005).

Bear's breech or mountain thistle (Acanthus montanus (Nees) 
T. Anderson) belonging to Acanthaceae family is a shrub widespread in Africa, the Balkans, Romania, Greece, and Eastern Mediterranean. It is widely engaged ethnomedicinally for the management of bacterial infection. The common names of Acanthus montanus are alligator plant, bear's breeches, and mountain thistle. In Nigeria, the plant is locally called cogwudurunwashishi' (Ibo), ebe-igbe' (Akoko-Edo) 'karinkan' (Yoruba). The various popular names it is called in southern Nigeria are "Elele-nyijuo", "Agamsoso" and "Agameru" (Igoli et al., 2004). It is used in African traditional medicine for the treatment of urogenital infections, urethral pain, endometritis, urinary disease, cystitis, leucorrhoea, aches, and pains. In south-eastern Nigeria, the root is popular and acclaimed highly effective in the treatment of furuncles (Okoli et al., 2008). The roots are used for bathing to relieve aches and pains (Ibe and Nwufo, 2005). The pharmacological activities of the plant leaves are documented shown to possess spasmolytic (Adeyemi et al., 1999) anti-inflammatory, analgesic, and antipyretic properties (Okoli et al., 2008).

The aim of this study was phytochemical screening, estimation of total flavonols content and evaluation of antioxidant activities of Acanthus montanus leaf extracts prepared using different solvents.

\section{MATERIALS AND METHODS}

\subsection{Plant collection and extraction}

Fresh leaves of $A$. montanus were collected from the Forestry Research Institute of Nigeria (FRIN) herbal garden. The plant was identified at the Forestry Herbarium, Ibadan (FHI) with voucher number, 106265 . The leaves were washed with caution and air-dried in the laboratory for six weeks and blended to a fine powder.

About $200 \mathrm{~g}$ of the powdered sample was soaked in $400 \mathrm{~mL}$ each of the organic solvents for $24 \mathrm{~h}$. The organic solvents used were ethyl acetate, acetone, and methanol respectively. The resulting mixture was filtered using Whatman qualitative filter paper (Sigma-Aldrich, Germany). The filtrate was then freeze-dried. To achieve the required concentration needed for this study, each extract was re-liquefied in its respective solvent.

\subsection{Phytochemical screening of plant extracts}

Phytochemical screening of flavonoids, saponins, phenols, terpenoids, phlobatannins, alkaloids, tannins, and cardiac glycosides was performed by using the colorimetric tests according to standard procedures with some modifications.

\subsubsection{Saponins determination}

To $5 \mathrm{~mL}$ of distilled water in a test tube was added $1 \mathrm{~mL}$ each of the plant extracts and vigorously shaken. A stable persistent effervescence was observed for a positive test (Evans and Trease, 1989).

\subsubsection{Terpenoids determination}

Concentrated $\mathrm{H}_{2} \mathrm{SO}_{4}$ solution $(1.5 \mathrm{~mL})$ was added to a mixture of $1 \mathrm{~mL}$ of chloroform and $2.5 \mathrm{~mL}$ of each of the plant extracts A reddish-brown color formation at the interface indicates the presence of terpenoids (Ghasham et al., 2017).

\subsubsection{Phlobatannins determination}

To $1 \mathrm{~mL}$ each of the plant extracts was added $1 \% \mathrm{HCl}$ acid solution $(1 \mathrm{~mL})$. The mixture was boiled and the formation of a red precipitate was observed for a positive test (Ghasham et al., 2017).

\subsubsection{Alkaloids determination}

To $2 \mathrm{~mL}$ of the plant extracts was added $0.2 \mathrm{~mL}$ of $1 \% \mathrm{HCl}$ acid in a test tube. $1 \mathrm{ml}$ of Wagner's reagent was then added to the mixture. The presence of alkaloids was indicated by a yellowish buff precipitate (Ghasham et al., 2017).

\subsubsection{Tannins determination}

To $1 \mathrm{~mL}$ each of the plant extracts was added 2-3 drops of $1 \%$ lead acetate solution. The appearance of dark blue or greenishgrey color indicates the presence of tannins (Ghasham et al., 2017).

\subsubsection{Cardiac glycosides determination}

In $1 \mathrm{~mL}$ of chloroform was dissolved $1 \mathrm{~mL}$ each of the plant extracts, then 2-3 drops of $10 \% \mathrm{H}_{2} \mathrm{SO}_{4}$ solution was added at the side of the test tube to form a layer. The formation of a brown ring at the interphase indicates the presence of deoxy sugar characteristics of cardiac glycosides (Ghasham et al., 2017).

\subsubsection{Flavonoids determination}

To $1 \mathrm{~mL}$ of $10 \%$ lead acetate solution was added $1 \mathrm{~mL}$ each of the plant extracts. The presence of flavonoids indicates a yellow-colored precipitate (Ghasham et al., 2017).

\subsubsection{Phenols determination}

Into $0.5 \mathrm{~mL}$ of $10 \%$ ethanolic ferric chloride solution was added $1 \mathrm{~mL}$ each of the plant extracts. A positive test was taken for the formation of blue-green to dark blue coloration (Ghasham et al., 2017).

\subsection{Estimation of total flavonols content}

Total flavonols content was determined by adopting the procedures described by Jimoh et al. (2018) using quercetin (QE) as standard. The reaction mixture consisting of $2 \mathrm{~mL}$ of $\mathrm{AlCl}_{3}$ prepared in ethanol and $3 \mathrm{~mL}$ of $(50 \mathrm{~g} / \mathrm{L})$ sodium acetate solution added to $2 \mathrm{~mL}$ each of the plant extracts was allowed to incubate for $2.5 \mathrm{~h}$ at $20^{\circ} \mathrm{C}$ severally. Absorbance at $440 \mathrm{~nm}$ was measured using a spectrophotometer. Total flavonols content was calculated as QE equivalents in mg per $g$ of extracts and expressed in mean \pm standard deviation from the calibration curve using the equation:

$$
Y=0.0255 X ; \quad R^{2}=0.9812,
$$

where $\mathrm{X}$ is the absorbance and $\mathrm{Y}$ is the $\mathrm{mg}$ of the quercetin equivalent.

\subsection{Antioxidant Assays}

\subsubsection{Scavenging activity of DPPH radical}

For DPPH radical assay, Liyana-Pathirana and Shahidi (2005) and Jimoh et al. (2018) procedures were followed. The effect of each extract on DPPH radical was evaluated. About 0.1 $\mathrm{mL}$ of DPPH-methanol solution $(0.135 \mathrm{mM})$ was mixed with $1.0 \mathrm{~mL}$ of different concentrations $(0.025-0.5 \mathrm{mg} / \mathrm{mL})$ of the various extracts of $A$. montanus leaf. The reaction mixture was vortexed thoroughly and left in the dark at room temperature for $30 \mathrm{~min}$. The absorbance of the mixture was measured spectrophotometrically at $517 \mathrm{~nm}$. Rutin and ascorbic acid were used as standard drugs. The percentage of free radical scavenging was calculated according to the following equation:

$$
\text { Scavenging activity }[\%]=\frac{A b s_{\text {control }}-A b s_{\text {sample }}}{A b s_{\text {control }}} \times 100,
$$

where $\mathrm{Abs}_{\text {control }}$ is the absorbance of DPPH + methanol; $\mathrm{Abs}_{\text {sample }}$ is the absorbance of DPPH radical + sample extract/standard. 


\subsubsection{Nitric oxide radical (NO') scavenging activity}

Ebrahimzadeh et al. (2010) procedure was followed for the scavenging of nitric oxide radical ( $\mathrm{NO}^{\circ}$ ) assay. A volume of $2 \mathrm{~mL}$ of $10 \mathrm{mM}$ sodium nitroprusside dissolved in $0.5 \mathrm{~mL}$ phosphate buffer saline ( $\mathrm{pH} 7.4$ ) was mixed with $0.5 \mathrm{~mL}$ of each plant extract, and ascorbic acid at various concentrations (0.025- $0.5 \mathrm{mg} / \mathrm{mL}$ ). The mixture was incubated at $25^{\circ} \mathrm{C}$ for 150 min. An aliquot of $0.5 \mathrm{~mL}$ of the solution was withdrawn and mixed with $0.5 \mathrm{~mL}$ of Griess reagents $(1.0 \mathrm{~mL}$ sulfanilic acid reagent $(0.33 \%$ in $20 \%$ glacial acetic acid at room temperature for $5 \mathrm{~min}$ with $1 \mathrm{~mL}$ of naphthyl ethylenediamine dichloride $(0.1 \% \mathrm{w} / \mathrm{v})$. The reaction mixture was incubated at room temperature for $30 \mathrm{~min}$, after which absorbance was measured at $540 \mathrm{~nm}$. The amount of nitric oxide radical was calculated using the equation:

$$
\text { Inhibition of } \mathrm{NO}^{*}[\%]=\frac{A_{0}-A_{1}}{A_{0}} \times 100,
$$

where $A_{0}$ is the absorbance before reaction and $A_{1}$ is the $a b$ sorbance after the reaction has taken place.

\subsection{Data analysis}

$\mathrm{IC}_{50}$ - the concentration of a drug, extract, or antibiotic required to cause $50 \%$ inhibition in vitro - was calculated for the two antioxidant activities engaged in this study (DPPH and nitric oxide) by using ED50V10 add-in on Excel.

Table 1. Phytochemical screening results for Acanthus montanus leaf extracts

\begin{tabular}{lccc}
\hline & \multicolumn{3}{c}{ Extract type } \\
\cline { 2 - 4 } Phytochemicals & Ethyl acetate $^{\mathrm{a}}$ & Acetone & Methanol \\
\hline Flavonoids & + & + & + \\
Saponins & - & - & - \\
Phenols & + & + & + \\
Terpenoids & + & + & + \\
Phlobotannins & - & - & - \\
Alkaloids & - & - & - \\
Tannins & - & - & - \\
Cardiac glycosides & - & + & +
\end{tabular}

a Signs plus (+) and minus (-) denote presence or absence of phytochemicals, respectively.

\section{RESULTS AND DISCUSSION}

\subsection{Phytochemical screening of Acanthus montanus leaf extracts}

This study considered using three extraction solvents according to their polarity (methanol, ethyl acetate, and acetone) to comparatively extract chemical compounds present in the leaves of Acanthus montanus. The phytochemical screening revealed the presence of flavonoids, phenols, and terpenoids in all investigated extracts. On the other hand, cardiac glycoside was only present in the acetonic and methanolic leaf extracts. However, saponins, phlobatannins, alkaloids, and tannins were absent in all organic extracts of the leaf (Table 1). Flavonoids are a diverse class of secondary metabolites with possibly useful health properties mostly distributed in plants (Zayachkivska et al., 2005) having the ability to scavenge free radicals (Okwu, 2004). This is an indication that $A$. montanus may be useful for the treatment of the oxidative stress-related disorder. Terpenes are added to creams and ointments to relieve pain and itching. Phenols and phenolic compounds have been extensively used in disinfection and remain the standards with which other bactericides are compared as a result of their immense antimicrobial properties (Okwu, 2001; Saxena et al., 2014). This may justify the ethnomedicinal uses of $A$. montanus for the treatment of endometritis, urinary diseases, and cystitis caused by bacteria. Terpenes also possess antimicrobial properties thus, helps to fight microorganisms resistant to antibiotics such as yeast and other fungi (Paduch et al., 2007; Santos et al., 2013). This shows that the leaves, as likewise noted by the roots by (Ibe and Nwufo, 2005), can also be used to relieve body aches and pains.

Cardiac glycosides were identified in methanol and acetone extract, and their absence in ethyl acetate extract may be as a result of weak solubility in ethyl acetate. This indicates the inefficiency of ethyl acetate as a phytochemical extraction solvent for Acanthus montanus leaves. Cardiac glycosides are a class of organic compounds that increase the output force of the heart and decrease its rate of contractions by acting on the cellular sodium-potassium ATPase pump with beneficial medicinal uses such as treatments for congestive heart failure and cardiac arrhythmia (Patel, 2016). This suggests the potential of $A$. montanus for the management of heart-related problems. However, this may not be true of the ethyl acetate extract as the cardiac glycosides were not identified in ethyl acetate extract in this study.

\subsection{Effect of extraction solvent on total flavonols content of Acanthus montanus leaf extracts}

The total flavonols content of $A$. montanus methanol extract 32.78 QE mg/g while the ethyl acetate and acetone extracts gave $12.89 \mathrm{QE} \mathrm{mg} / \mathrm{g}$ and $10.06 \mathrm{QE} \mathrm{mg} / \mathrm{g}$ respectively (Table 2). The phytochemical estimation of total flavonols content depicted methanol as the most potent phytochemical solvent of extraction because the methanol extract was the richest one in flavonols. This is in agreement with other studies (Dhawan and Gupta, 2016; Roy et al., 2016; Truong et al., 2019). Flavonols are a class of flavonoids that perform the function of expelling free radicals from the body through the liver. Quercetin, isorhamnetin, kaempferol, and myricetin are the most common flavonols found in foods. These flavonoid compounds exhibit antibacterial, antioxidant and anti-inflammatory properties in the body and have recently made huge significant progress as a factor related to decreasing the risk for Alzheimer's disease, which is gaining more public attention in countries with increasing aged populations (Tristantini and Pradana, 2017) (Huntington Lifestyle Partners, 2021).

Table 2. Total flavonols content of Acanthus montanus leaf extracts

\begin{tabular}{lr} 
Extract type & $\begin{array}{r}\text { Flavonols content } \\
{[\mathrm{QE} \mathrm{mg} / \mathrm{g}]^{\mathrm{a}}}\end{array}$ \\
\hline Ethyl acetate & $12.89 \pm 0.02$ \\
Acetone & $10.06 \pm 0.02$ \\
Methanol & $32.78 \pm 0.00$
\end{tabular}

a Values are presented as mean value \pm standard deviation of triplicate measurements. 


\subsection{Impact of different solvent on antioxidant activities of $\boldsymbol{A}$ montanus leaf extracts}

\subsubsection{Scavenging activity of DPPH radical}

The obtained DPPH result (Table 3) showed the lowest $\mathrm{IC}_{50}$ value observed in $A$. montanus acetone extract $(132.7 \pm 0.01$ $\mu \mathrm{g} / \mathrm{mL}$ ) corresponding to the most active extract while the ethyl acetate and methanol extract $(149.3 \pm 0.00 \mu \mathrm{g} / \mathrm{mL}$ and $164.6 \pm 0.01 \mu \mathrm{g} / \mathrm{mL})$ gave a considerable $\mathrm{IC}_{50}$ value. The observed $\mathrm{IC}_{50}$ value of the standard drug, ascorbic acid was $39.9 \pm 0.01 \mu \mathrm{g} / \mathrm{mL}$.

Table 3. DPPH antioxidant activity of Acanthus montanus leaf extracts

\begin{tabular}{lr}
\hline Extract type/Standard & $\begin{array}{r}\mathrm{IC}_{50} \\
{[\mu \mathrm{g} / \mathrm{mL}]^{\mathrm{a}}}\end{array}$ \\
\hline Ascorbic acid & $39.9 \pm 0.01$ \\
Ethyl acetate & $149.3 \pm 0.00$ \\
Acetone & $132.7 \pm 0.01$ \\
Methanol & $164.6 \pm 0.01$
\end{tabular}

${ }^{a}$ Values are presented as mean value \pm standard deviation of triplicate measurements.

Plants rich in antioxidants naturally have the ability to scavenge DPPH radicals due to their hydrogen-donating potential. The quantity of a plant extract essential to reduce the DPPH concentration by half $\left(\mathrm{IC}_{50}\right)$ in the DPPH assay is a degree of its antioxidant action; a lower $\mathrm{IC}_{50}$ value corresponds to a higher antioxidant power (Xie and Schaich, 2014). In this study, the acetone plant extract possessed the lowest $\mathrm{IC}_{50}$ value for all cases of antioxidant results. Thus, it suggests the best radical scavenging activity compared to its methanolic and ethyl acetate counterparts. This is in tandem with other studies, which revealed acetone extracts in maximum performance on antioxidant activity of certain plants - in comparison with other solvents of extraction (Dhawan and Gupta, 2016; Kobus-Cisowska et al., 2020). Apparently, it was observed that the antioxidant activity of $A$. montanus could be attributed to moderately polar extracts.

\subsubsection{Nitric oxide radical (NO') scavenging activity}

The obtained NO` scavenging activity results (Table 4 ) showed the lowest $\mathrm{IC}_{50}$ value observed in $A$. montanus acetone extract $\left(\mathrm{IC}_{50}\right.$ of $66.5 \mu \mathrm{g} / \mathrm{mL}$ ) corresponding to the most active extract; followed by $A$. montanus methanol extract $\left(\mathrm{IC}_{50}\right.$ of 138.5 $\mu \mathrm{g} / \mathrm{mL}$ ), and Acanthus montanus ethyl acetate extract $\left(\mathrm{IC}_{50}\right.$ of $142.6 \mu \mathrm{g} / \mathrm{mL}$ ). Ascorbic acid, standard drug, gave $\mathrm{IC}_{50} 12.1$ $\mu \mathrm{g} / \mathrm{mL}$

Table 4. Nitric oxide radical (NO*) scavenging activity of Acanthus montanus leaf extracts

\begin{tabular}{lr}
\hline Extract type/Standard & $\begin{array}{r}\mathrm{IC}_{50} \\
{[\mu \mathrm{g} / \mathrm{mL}]^{\mathrm{a}}}\end{array}$ \\
\hline Ascorbic acid & $12.1 \pm 0.01$ \\
Ethyl acetate & $142.6 \pm 0.02$ \\
Acetone & $66.5 \pm 0.00$ \\
Methanol & $138.5 \pm 0.00$ \\
\hline
\end{tabular}

$\bar{a}$ Values are presented as mean value \pm standard deviation of triplicate measurements.

\section{CONCLUSION}

Acanthus montanus methanol extract had the highest total flavonol content among the solvent systems used in this research while the acetone extract gave the best antioxidant activity. This study, therefore, provides evidence that various solvents used in extraction can result in variation in phytochemical constituents, significant differences in quantitative phytochemicals, and antioxidant activity. However, further biological and chemical studies are required to further observe the phytochemical estimation and isolate the bioactive compounds to know the compounds responsible for the observed antioxidant activity of these medicinal plants.

\section{FUNDING}

This research has been funded by Forestry Research Institute of Nigeria.

\section{ACKNOWLEDGMENTS}

Authors appreciate the support of technologist from Biomedicinal Research Centre and also the curator in the herbal garden unit for creating an enabling environment for this study.

\section{REFERENCES}

Adam, A. A. and Omogbene, T. O. (2020). Phytochemical and phytomineral (macro and trace) compositions of the leaf, stem bark and root of Blighia sapida K.D. Koenig, Journal of Medicinal Plants Studies 8(5): 20-24.

Adeyemi, O. O., Okpo, S. O. and Young-Nwafor, C. C. (1999). The relaxant activity of the methanolic extract of Acanthus montanus on intestinal smooth muscles, Journal of Ethnopharmacology 68(1-3): 169-173.

Aliyu, A. B., Musa, A. M., Oshanimi, J. A., Oshanimi, J. A., Ibrahim, H. and Oyewale, A. O. (2008). Phytochemical analyses and mineral elements composition of some medicinal plants of Northern Nigeria, Nigerian Journal of Pharmaceutical Sciences 7(1): 119-125.

Bandaranayake, W. M. (2006). Quality control, screening, toxicity, and regulation of herbal drugs, in I. Ahmad, F. Aqil and M. Owais (eds), Modern Phytomedicine, Wiley-VCH Verlag GmbH \& Co. KGaA, Weinheim, Germany, pp. 25-57.

Benkeblia, N. (2004). Antimicrobial activity of essential oil extracts of various onions (Allium cepa) and garlic (Allium sativum), LWT - Food Science and Technology 37(2): 263-268.

Chukwujekwu, J., van Staden, J., Smith, P. and Meyer, J. (2005). Antibacterial, anti-inflammatory and antimalarial activities of some Nigerian medicinal plants, South African Journal of Botany 71(3-4): 316-325.

Dhawan, D. and Gupta, J. (2016). Comparison of different solvents for phytochemical extraction potential from Datura metel plant leaves, International Journal of Biological Chemistry 11(1): 17-22.

Ebrahimzadeh, M. A., Nabavi, S. M., Nabavi, S. M., Nabavi, S. F. Bahramian, F. and Bekhradnia, A. (2010). Antioxidant and free radical scavenging activity of $H$. officinalis $L$. var. angustifolius, $V$. odorata, B. hyrcana and C. speciosum, Pakistan Journal of Pharmaceutical Sciences.

Evans, W. C. and Trease, G. E. (1989). Trease and Evans' pharmacognosy, Baillière Tindall, London; Philadelphia. OCLC: 21198097.

Ghasham, A. A., Muzaini, M. A., Qureshi, K. A., Osman, G., Khan, R. A., Farhana, S. A., Hashmi, S., El-Agamy, E. and Abdallah, W. E. (2017). Phytochemical screening, antioxidant and antimicrobial activities of methanolic extract of Ziziphus mauritiana Lam. leaves collected from Unaizah, Saudi Arabia, International Journal of Pharmaceutical Research \& Allied Sciences 6(3): 33-46.

Hassan, B. A. R. (2012). Medicinal plants (importance and uses), Pharmaceutica Analytica Acta 03(10).

Hussein, R. A. and El-Anssar, A. A. (2018). Plants secondary metabolites: The key drivers of the pharmacological actions of medicinal plants, in P. F. Builders (ed.), Herbal Medicine, IntechOpen.

Ibe, A. and Nwufo, M. I. (2005). Identification, collection and domestication of medicinal plants in Southeastern Nigeria, Africa Development 30(3). 
Igoli, J. O., Igwue, I. C. and Igoli, N. P. (2004). Traditional medicinal ractices among the Igede people of Nigeria, Journal of Herbs, Spices \& Medicinal Plants 10(4): 1-10.

Jimoh, W. A., Fagbenro, O. A. and O., A. E. (2018). Digestibility coefficients of processed jackbean meal Cannavalia ensiformis (L.) DC for Nile tilapia, Oreochromis niloticus (linnaeus, 1758) diets, African Journal of Fisheries Science 6(1): 001-006.

Kobus-Cisowska, J., Szczepaniak, O., Szymanowska-Powałowska, D., Piechocka, J., Szulc, P. and Dziedziński, M. (2020). Antioxidant potential of various solvent extract from Morus alba fruits and its major polyphenols composition, Ciência Rural 50(1): e20190371.

Krishnaraju, A. V., Rao, T. V. N., Sundararaju, D., Vanisree, M., Tsay, H.-S. and Subbaraju, G. V. (2006). Biological screening of medicinal plants collected from Eastern Ghats of India using Artemia salina (Brine shrimp test), International Journal of Applied Science and Engineering 4(2): 115-125.

Lawal, I. O., Olufade, I. I., Rafiu, B. O. and Aremu, A. O. (2020b). Ethnobotanical survey of plants used for treating cough associated with respiratory conditions in Ede South local government area of Osun state, Nigeria, Plants 9(5): 647.

Lawal, I., Omogbene, T. and Adam, A. (2020a). Phytomenadione as a dietary supplement: Sources and health benefits, Preparation of phytopharmaceuticals for the management of disorders, Elsevier, pp. 381389.

Liyana-Pathirana, C. M. and Shahidi, F. (2005). Antioxidant activity of commercial soft and hard wheat (Triticum aestivum L.) as affected by gastric $\mathrm{pH}$ conditions, Journal of Agricultural and Food Chemistry 53(7): 2433-2440.

Moyo, M., Aremu, A. O. and Van Staden, J. (2015). Medicinal plants: An invaluable, dwindling resource in sub-Saharan Africa, Journal of Ethnopharmacology 174: 595-606.

Okoli, C. O., Akah, P. A., Onuoha, N. J., Okoye, T. C., Nwoye, A. C. and Nworu, C. S. (2008). Acanthus montanus: An experimental evaluation of the antimicrobial, anti-inflammatory and immunological properties of a traditional remedy for furuncles, BMC Complementary and Alternative Medicine 8(1): 27.

Okwu, D. E. (2001). Evaluation of chemical composition of indeginous species and flavouring agents, Global Journal of Pure and Applied Sciences 7(3): 455-460. Number: 3.

Okwu, D. E. (2004). Phytochemicals and vitamin content of indigenous spices of South Eastern Nigeria, Journal of Sustainable Agriculture and the Environment 6(1): 30-37.

Paduch, R., Kandefer-Szerszeń, M., Trytek, M. and Fiedurek, J. (2007). Terpenes: substances useful in human healthcare, Archivum Immunologiae et Therapiae Experimentalis 55(5): 315.

Patel, S. (2016). Plant-derived cardiac glycosides: Role in heart ailments and cancer management, Biomedicine \& Pharmacotherapy 84: 10361041.

Pieme, C., Dzoyem, J., Kechia, F., Etoa, F. and Penlap, V. (2008). In vitro antimicrobial activity of axtracts from some Cameroonian medicinal plants, Journal of Biological Sciences 8(5): 902-907.

Roy, S., Pawar, S. and Chowdhary, A. (2016). Evaluation of in vitro cytotoxic and antioxidant activity of Datura metel Linn. and Cynodon dactylon Linn. extracts, Pharmacognosy Research 8(2): 123.

Santos, M. L., Magalhães, C. F., Rosa, M. B. d., Santos, D. d. A., Brasileiro, B. G., Carvalho, L. M. d., Silva, M. B. d., Zani, C. L., Siqueira, E. P. d., Peres, R. L. and Andrade, A. A. (2013). Antifungal activity of extracts from Piper aduncum leaves prepared by different solvents and extraction techniques against dermatophytes Trichophyton rubrum and Trichophyton interdigitale, Brazilian Journal of Microbiology 44(4): 12751278.

Saxena, H. O., Soni, A., Mohammad, N. and Choubey, S. K. (2014). Phytochemical screening and elemental analysis in different plant parts of Uraria picta Desv.: A Dashmul species., Journal of Chemical and Pharmaceutical Research 6(5). Publisher: Journal of Chemical and Pharmaceutical Research.

Sofowora, A. (1996). Research on medicinal plants and traditional medicine in Africa, The Journal of Alternative and Complementary Medicine 2(3): 365-372.

Tristantini, D. and Pradana, B. T. (2017). Anti-cholesterol activity test of tanjung (Mimusops elengi L.) leaf extract in the water using in vivo method in mice (Mus musculus L.) DDY-strain, Depok City, Indonesia, p. 030009.

Truong, D.-H., Nguyen, D. H., Ta, N. T. A., Bui, A. V., Do, T. H. and
Nguyen, H. C. (2019). Evaluation of the use of different solvents for phytochemical constituents, antioxidants, and in vitro anti-inflammatory activities of Severinia buxifolia, Journal of Food Quality 2019: 1-9.

WHO (2005). WHO global atlas of traditional, complementary and alternative medicine, World Health Organization, Geneva, Switzerland.

Xie, J. and Schaich, K. M. (2014). Re-evaluation of the 2,2-Diphenyl1-picrylhydrazyl Free Radical (DPPH) Assay for Antioxidant Activity, Journal of Agricultural and Food Chemistry 62(19): 4251-4260.

Zayachkivska, O. S., Konturek, S. J., Drozdowicz, D., Konturek, P. C., Brzozowski, T. and Ghegotsky, M. R. (2005). Gastroprotective effects of flavonoids in plant extracts, Journal of Physiology and Pharmacology: An Official Journal of the Polish Physiological Society 56 Suppl 1: 219231. 